\title{
TURKISH TRANSLATIONS OF SHAKESPEARE'S WORKS: LITERARY INTEGRATION
}

\section{Iryna Prushkovska ${ }^{1}$}

DOI: https://doi.org/10.30525/978-9934-26-077-3-18

Abstract. The article is devoted to the analysis of the functioning of Turkish translations of Shakespeare's poetry and dramaturgy, the formation of a holistic picture of the stages of discovery of Shakespeare by the Turks. The aim of the study is to identify and present the main points related to the transfer of Shakespeare's word into Turkish culture through translations from European languages. The proposed study is focused on translation aspects, as translation has become the first link in the dialogue between English and Turkish literature during the contact and interaction of Turkish literature with the Western, the processes of familiarization of the Shakespeare with the Turks, the perception and reproduction of Shakespeare's creativity on Turkish soil. In this study we used such methods as the cultural-historical method, which focuses on the translation of Shakespeare's works in relation to the cultural-historical development of Turkish society; a comparative method aimed at comparing the original sonnets and dramas of Shakespeare with translations into Turkish; receptive-aesthetic method, focused on focusing on how the pictorial and expressive artistic means of Shakespeare's works in Turkish translations are projected on the recipient (reader), convey to him the author's idea. Particular attention is focused on the translation analysis of some sonnets and dramas. Working with factual material revealed the basic prerequisites for entry into the Turkish literature of Shakespeare's works (Divan literature, the period of reforms), made it possible to characterize the first stage of translation studies - namely, the translation of Shakespeare through the prism of the French language, and accordingly the translation from the French language. As a result, we conclude that no artistic translation, especially poetic one, can be definitive, since there are always unrealized reserves of the original hidden in the

${ }^{1}$ Doctor of Philology, Associate Professor,

Associate Professor at the Department of Foreign Languages,

Taras Shevchenko National University of Kyiv, Ukraine 
multifacetedness of its associative relations. And each translation is only a certain link, the voicing of voices in the process of functioning of the artistic image. This can be explained by the considerable number of translations in Turkish of both the poetic and dramatic works of Shakespeare from the second half of the 19th century to the present. Also the great potential of the Turkish youth in the translation field has been revealed, which is certainly facilitated by the popularity of English and literature in higher education. institutions.

\section{Introduction}

Turkish literature is a distinctive phenomenon that was formed under the influence of different cultures and traditions (Arab-Persian, Western, and Turkish). Each of the penetrations into the Turkish literature of certain elements led to changes in the structure and form of the literature. Such changes were undoubtedly positive and also had negative consequences in some moments. However, if we analyse the situation in general, most innovations in Turkish literature have diversified it, formed new forms, images, and literary trends. Given the particularities of Turkish culture as Eastern, the persistence of certain traditions, the domination of non-Western Muslim religions in some places slowed down the process of interaction with different cultures, but the process was still inevitable.

Talking about the domination in the Turkish literature of Shakespeare's word, we should touch on the main points, namely: contact and interaction of Turkish literature with the Western, the processes of familiarization of the Shakespeare with the Turks, the perception and reproduction of Shakespeare's creativity on Turkish soil. The proposed study will focus on translation aspects, as translation has become the first link in the dialogue between English and Turkish literature.

\section{Historical prerequisites for Western Turkish literary contacts}

More than five centuries in the Turkish culture dominated ArabPersian influence (up to the beginning of the nineteenth century), which significantly affected the subject, form, content of literary works of Turkish authors. At a time when the sun of the Renaissance was shining over Europe, Turkish literature developed in the Ottoman realm of Eastern customs and traditions. It was the Middle Ages, the time frames of which 
differ from those of Europe. At that time, Turkish literature can be roughly divided into the literature of the early Middle Ages (Rumi, Yunus Emre, Gülschegri, Sheikh) and the literature of the late Middle Ages (Nephi, Nabi, Sheikh Galib). The second half of the eighteenth century - beginning of the XIX century can be considered a pre-Renaissance era.

For the Ottoman Empire of the XIII century was a tragic period, a period of Tatar-Mongol invasion, fire, death, suffering. But history knows a great deal of evidence that its most tragic periods reveal the highest creative potential in person. In trials, the spirit is tempered, reaching a level of spirituality that is not subject to the forces of worldly evil. An example of such high spirituality and unwavering faith is the work of Rumi (1207-1273) [6, p. 11]. The poets of the early Middle Ages (13th-16th centuries) were the main propagators of Sufi thought. The poetry of Sufi theorists has become a major tool in the pursuit of philosophicalreligious, moral-ethical and artistic-aesthetic goals. They were able to solve the most difficult questions of their time in their poetry. If there have been differences between poetry and philosophy for centuries, then Sufism has moved them into a single line. For centuries, literature has been the basis for prosperity and domination through the flow of Tasawwuf.

The XVII century in the Ottoman Empire signs of both economic and political decline became noticeable. Although this did not apply to culture and literature. The main tendency in the literature was its nationalization, appeal to the vernacular, purely Turkish vocabulary, Turkish adverbs and sayings, and less interest in Iranian literature. "A prominent feature of Turkish writing of this era, and in particular of the poetry of the Divan, is the growing echo of the ideology of urban culture, which has led to the expansion of the public sphere of literature" [5, p. 7]. New genres, themes, characters, and new styling are emerging, with Indian poetry becoming the hallmark of sofa poetry. Indian style was admired by almost all poets of the seventeenth century.

In the early eighteenth century, during the reign of Sultan Ahmet III (1703-1730), the Ottoman Empire showed great interest in Europe, European literature. However, the interest itself was not backed up by the possibility of familiarizing the public with examples of European literature. Therefore, the XVIII century in the Ottoman state is characterized as an example of the turning point, and is a vivid presentation of the best works 
of recent poets of Divan literature (Sheikh Galib, Nedim), the end of the era of domination of Divan literature, the conditional boundary between classical Turkish literature. It is worth noting that in the XVIII century. The desire of the Turkish literary elite to make changes to the classic, annoying literary forms over the centuries, is felt, and the work of Sheikh Galib is a vivid confirmation of this. He began writing in Indian style to add new content to the literature of the Divan and to leave behind those traditions that had long been bored [10, p. 27]. Galib's language is heavier than that written by Turkish poets in the eighteenth century, because it had all the peculiarities of Indian style. The language of Galib's poetry is first and foremost subtle and witty. He found words of subtle, deep meaning, comprehending each word and its place in the beyt. Like all Indian-style poets, he made extensive use of foreign words, especially Persian. He has a notable preference for words with abstract meanings that are easily combined with words with specific meanings. Hasan Gusrev Hathemi believes that Galib opposed his method to established traditions, reached the perfection of his works, going beyond the style of Divan literature $[9$, p. 47]. By the way, the most prominent features of Indian-style poetry are the sophistication and sophistication of the metaphor and the freshness of comparison [5, p. 56]. During the heyday of Indian-style poetry, many new words and phrases emerge, the word is filled with profound content, becomes laconic and aphoristic. Considering these characteristics of Indian style, it can be safely stated that if during the life of Galib the Ottomans had already started translating from Western languages, then Galib could be one of Shakespeare's best translators.

The reforms of Sultan Selim III, and later Mahmud II (rule 1808-1839), had a significant impact on the politics, economy, culture, and education of the Ottoman state. Until the reform period, the main focus of education was the medrese, where they studied the basics of Islam, Arabic and Persian, Divan literature. Along with the reform, new areas of education have emerged - ordinary in our understanding of schools that have brought up a new generation of Turkish youth with new views on culture and literature. Reforms were one of the root causes of the emergence in Turkish classical literature, the traditional theatre of Western elements, which subsequently contributed to the emergence of new literary genres, radically changed the structure of classical national drama. 
The influence of Western tendencies became significant at the beginning of the 19th century in the Tanzimat era (the era of Ottoman reform). The connection of the Ottoman Empire with Europe, first France, took place even before the reforms of 1839 by Suleiman Agha and Yirmisekiz Celebi Megmet Effendi. Signed between France and the Ottoman state in 1740, the so-called «capitulation» document for a long time was the basis of privileges for France: the French were given the right and freedom to trade in the territory of the Ottoman state under the full protection of the Sultan, the French consuls had judicial power, there were no restrictions on religious and cultural plans.

For the first time in the classical Turkish literature, western elements began to appear due to the study of French by the Turks and the emergence of translations of works by Western artists, mainly from French. Perspective of visiting France by representatives of the Turkish literary elite for the purpose of learning the language and getting acquainted with the French culture (Ibrahim Shinashi, Namik Kemal); institutions have all contributed to the rapid «entry» of French cultural tradition into Turkish literature, as well as to European cultural heritage through French sources. A further stage in the «entry» of French culture into Turkish was the numerous translations into Turkish of works by French authors (Hugo, Zola, Maupassant, Goncourt brothers, Stendhal, Balzac), and in 1832 a union of translators was established in Istanbul. Above all, documents on military affairs, scientific works on medicine, and later (since 1859) works of art of the Enlightenment, Romanticism, Realism were translated by Turkish writers at that time. An important role in the promotion of French culture was played by the literary magazine Servet-i Funun (1891-1944), around which such poets and writers like Tevfik Fikret, Nazim Nabizade, Hussein Rahmi Gyurpinar united. This is an important fact, because, as will be discussed later, it is French that will for a long time become the main link between Shakespeare's works and their translations into Turkish. Such new genres for Turkish literature as novel, drama attracted the attention of writers of that time. From the second half of the nineteenth century, when numerous reforms and changes in the Ottoman state literally broke the window into the European cultural space, Turkish literature began to catch up with those literary trends that had long taken place in Europe. At that time, theatrical troupes from different European countries were increasingly coming to the largest cities of the Ottoman Empire. 
In 1840, the first theatre was opened in Istanbul, where plays, mainly translated from French and English, were staged. According to the Turkish scientist A. H. Tanpinar, it was in 1842 that the beginning of dramaturgy in the European sense could be called [20, p. 155]. It was the appearance of the Turkish author's drama and the opening of the theatres that contributed to the Turks' discovery of Shakespeare's work primarily through translations. For by that time, even if there were some translation efforts and presentations to the Turks of Western European works, there would probably have been a cultural rejection due to the lack of relevant literary genres. Because by the nineteenth century. The Turkish culture was dominated by folk drama, traditional folk theatre («Ortaoyunu», «Karagyoz», «Kukla Oyunu», performances of medakhs). As already mentioned, the Turkish reader and viewer first became acquainted with the French literature, the French theatre. Moliere's works had a great influence on the formation of a western-style Turkish comedy in the second half of the nineteenth century. The works of the French comedian have become the basis of comedies of the European variety not only in the Ottoman state, but also in many Islamic countries: Azerbaijan (Mirza Feth-Ali Akhundzade), Iran (Habib Isfahani, Muhammad Hassan Khan), Lebanon (Marqun el-Marun el-Ahran). (Jakub Ibn Rufail Sanua) [7, p. 51]. After exploring Moliere's works, the Turks discover Shakespeare, Shakespeare in French interpretation.

\section{Translational interpretations of Shakespeare's poetic work}

Speaking about the translation into Turkish of poetic works by Shakespeare, there are two important stages: 1) translations from French (translation through translation) and 2) translations from English (direct translation of the original). As noted earlier, with the emergence of the opportunity to discover the Western world of culture, the Turkish intelligence very actively introduced the works of French, English, German, Slavic authors, using existing sources of French, because it was French that became the first and the only Western foreign language that the Turks have learned for a while. That is why more than a century ago, Shakespeare's works were presented in Turkish through French translations. Speaking of poetic translation into Turkish by Western authors, and in particular Shakespeare's poetry, along with the linguistic aspect, was a peculiarity of the Turkish verse system, which was not adapted to the exact reproduction of poetry 
by Western artists. After all, as is well known, the complexity of translation of poems, a form of poetic speech, the basis of which is metric, rhythmic, rhyming, is generally recognized. Most poets and translators from different countries have expressed the view that poetic translation is «the most difficult and ungrateful of all kinds of literature». It is argued that a poetic translation must adhere to the requirements of three correspondences. The first is equilinearity, that is, correspond to stanzas and lines. The second is the equimetry - the observance of the system of alternation of stressed and unstressed groups of warehouses. The third is equirhythmicity, the observance of the rhythm of the poem. Rhythm is a wavy change in the ways in which the poem is organized. This includes changing metric, rhyme, number of lines in a stanza, and more.

At the time of the Europeanisation of Turkish literature, Turkish poets continued to actively use the system of quantitative rotation of the aruz, based on the alternation of long and short syllables and closely linked to the Arabic version and features of the Arabic language. Such a system of verse made it impossible for the poetic translation of Western poetic works. Turkish poets, in order to overcome the existing problem, decide to renew the poetic size of the hedge, which was previously used mainly in folk literature and was unacceptable in Divan literature. However, there were some limitations here for translation, as the size of the hedge also had some specificity (the same number of syllables and each line of poetic work). And only in the early twentieth century in Turkish poetry influenced by Western trends appeared free verse, which resorted to both Turkish poets for writing their own works and translators of works of Western artists, in order to acquaint Turks with world literary work, being forced to ignore the rules of translation. It is known that in the vast world of Shakespeare's work, his poems and sonnets occupy a separate area. They are, as it were, an autonomous province with their laws and customs, which in many respects differ from those that are inherent in drama [1, p. 216]. Shakespeare's compositionally poetic works obey the strict laws of architecture. In them we find the exact balance of proportions, sonnets - a miracle of strict and clear architectonics. Shakespeare's rhythmic mastery is manifested in how he managed to give a variety of sound to the stiff and constant stanza of the sonnet [1, p. 220]. Given above, it becomes clear how difficult it was for the Turks to convey in their language all the features of Shakespeare's poetry. 
Thus, the first presentation to the Turkish translation of Shakespeare's poetry took place in 1884 (dramatic works of Shakespeare were translated several years earlier). Expert of French language Hüsnü Osman has published a collection of 132 Shakespeare sonnets, translating them into Turkish from French prose by V. Hugo. 1887-1888 Mehmet Nadir translated 41 Shakespeare sonnets $(14,24,27,28,38,43-44,46-47,56,63,75,78,79$, $81,83,84,91-93,95-96,106,109-114,132,138-142,15,147-150,154)$ in a genre of poetry in prose with elements of the poetic traditions of literature of the Divan and published in the literary newspaper «Tarik») [8, p. 106]. In doing a thorough study of the sonnet translations by Mehmet Nadir, Inji Enginyun notes that overall the impressions of the translation are as positive as possible, and the translator adheres to the basic rules of verbal test transmission, while maintaining the cultural aspect of the original language. The only thing that I. Enginyun pays special attention to is the frequent use of the word-synonym, which is characteristic of the Turkish language as a whole (to use alongside the word-synonyms of Arabic origin and purely Turkish): beauty's form - hüsn ü cemal, draw - tasvir ve tersim, pain - mihen ü meşakk, love - aşk ve alaka [8, p. 106].

In addition, in 1888 Mehmet Nadir published in the «Tarik» newspaper a part of «Venus and Adonis», «The Rape of Lucrece» and a full translation of «The Lover's Complaint». Muallim Naci (1850-1895) also translated 8 Shakespeare sonnets $(9,27,43,44,63,91,104,105)$ and published in the newspapers «Tercüman-1 Hakikat» and «Berk» [8, p. 115]. However, as I. Enginyun notes, the Turkish version of Shakespeare's sonnets is burdened with additional phrases, words that distance the translation from the original $[8$, p. 116]. It should be noted that both Mehmet Nadir and Muallim Naci translated not from the original, but from the French translation by Victor Hugo. Turkish poet, translator, connoisseur of Greek and Latin, European history and art Can Yücel (1926-1999) translated some of Shakespeare's sonnets and several plays. Known for his widespread use in his own poetry of vernacular, jargon, Can Yücel used it in the poetic translations. Despite many criticisms towards his translations, he continues to advocate a free interpretation of translations, considering it the right of his own vision of a work, the desire to get European literature as close as possible to Turkish realities. His peculiar approach to translation had his adherents (Zeynep Oral, Talat Sait Halman); his original translation of Shakespeare's 66 sonnet 
inspired the musicians of Ezginin Günlüğü Hüsnü Arkan to a musical interpretation of the sonnet:

\section{Sone}

Vazgeçtim bu dünyadan tek ölüm paklar beni,

Değmez bu yangin yeri, avuç açmaya değmez.

Değil mi ki çiğnenmiş inancın en seçkini,

Değil mi ki yoksullar mutluluktan habersiz,

Değil mi ki ayaklar altında insan onuru,

O kız oğlan kız erdem dağlara kaldırılmış,

Ezilmiş, hor görülmüş el emeği, göz nuru,

Ödlekler geçmiş başa, derken mertlik bozulmuş,

Değil mi ki korkudan dili bağlı sanatın,

Değil mi ki çılgınlık sahip çıkmış düzene,

Doğruya doğru derken ĕgriye çıkmış adın,

Değil mi ki kötüler kadı olmuş Yemen'e,

Vazgeçtim bu dünyadan, dünyamdan geçtim ama,

Seni yalnız komak var, o koyuyor adama.

It is known that when translating the forms of poems from one language to another, translator cannot violate the forms and laws of that language $[2$, p. 141], it is impossible to extend or shorten a poem without changing its tone, even if the number of images is preserved. Both conciseness and amorphousness of the image are foreseen by design, and each extra or lost line changes the measure of its intensity. However, the translation practice assumes that in some cases the translator has the right to leave the holistic image of the poet and accordingly change one or another line, the word [2, p. 51]. Analyzing Yücel's translation from the point of view of conformity of the original is not easy, because it is not known exactly what he took as the basis - the original or translations from French. The only thing that can be noted with certainty are the replicas, which most likely are not the result of inaccuracies of translation, but rather a feature of the style of Jan Yücel, mentioned above. Yes, the first lines are translated from Turkish as «I give up my life - only death will cleanse me», «Do not deserve this place of fire open with the prayer of my palms», the fourth: «And that the poor have not heard anything about riches», the penultimate where Shakespeare is about good and evil - «Bad people are judges in Yemen». Whether free translations of such great artists as Shakespeare have the right to exist of this type is open and, 
more likely, with a positive answer, since they exist not only in Turkish but also in many others. However, one should be as careful as possible with the perception and use of such translations, understanding and not forgetting the subjective interpretation, the distance from the original. It is not acceptable, of course, to introduce such a type of translation into media resources with a cover of «naturalness», as, for example, the journalist of the famous Turkish newspaper Sabah (January 20, 2014) H. B. Kahraman, analysing the democratic situation in to the country: «The source of democracy is virtue, and the source of virtue is the judge, because, as Shakespeare said, 'Bad people are judges in Yemen.'» [11].

It is worth noting that the intensification of teaching English in Turkey since 1956 (Anatolian Lyceum) contributed to the emergence of new translations of English literature, made from the original non-French translations. 1964 A well-known Turkish literary researcher, poet, writer, member of the poetry committee of America, Talat Sait Halman translated from the original and published 40 Shakespeare sonnets in one book. Given the accuracy of information on the reference of Talat Sait Halman to the original, we give his version of the translation of the 66 sonnets, which, compared with the translation of Jan Yücel, is the most consistent with the original, although it has certain features, losses, which is difficult to avoid in poetic translation.

\section{Sone}

Bıktım artık dünyadan, bari ölüp kurtulsam:

Bakın, gönlü ganiler sokakta dileniyor.

İşte kırtıpillerde bir süs, bir giyim kuşam,

İşte en temiz inanç kalleşçe çiğneniyor,

İste utanmazlıkla post kapmış yaldızlı şan,

İşte zorla satmışlar kızoğlankız namusu,

İşte gadre uğradı dört başı mamur olan,

Işste kuvvet kör-topal, devrilmiş boyu bosu,

İşte zorba, sanatın ă̆zına tıkaç tıkmış.

İşte hüküm sürüyor çllgınlık bilgiçlikle,

İşte en saf gerçeğin adı saflı̆̆a çıkmış,

İşte kötü bey olmuş, iyi kötüye köle;

Bıktım artık dünyadan, ben kalıcı değilim,

Gel gör ki ölüp gitsem yalnız kalır sevgilim. (Talât Sait Halman) 
The English form of the sonnet consists of three quatrains and a final couplet (verse) (a total of 14 lines). Accepted rhyme order: abab cdcd efef gg. This system is simpler than the Italian Petrarch scheme. Since Shakespeare used it, it was called Shakespearean. The first quatrain should contain an exposition, that is, an exposition of the topic, and the very first line should immediately introduce the reader to the topic of the poem. In the second quatrain, the theme is further developed, sometimes on the basis of opposition. The three verses give a solution to the topic, a summary, a conclusion from the author's thoughts. Shakespeare follows the usual pattern: the first quatrain contains an exposition of the topic, the second - its development, the third - leads to a dénouement, and the final couplet in an aphoristic laconic form expresses the result. When examining Shakespeare's Sonnets, it is necessary first to accurately imagine the requirements of the composition to which the poet had to subordinate his imagination. And in order to appreciate this art, one must learn to see how he was able to subordinate this rigid scheme to his plan, idea [1, p. 302]. Translated by Talat Sait Halman demonstrates translation skills: the Turkish version also has 14 lines, the rhyming order, as in the English sonnet (kurtulsam / dinleniyor / kuşam / çiğneniyor; şan / namusu / olan / bosu), is preserved.

By the way, Halman's excellent knowledge of English and culture, literary talent helped him become one of the first to translate not only English literature from the original, but also works by Turkish authors into English.

1979 the first complete collection of translations of all Shakespeare's sonnets by Bülent Bozkurt and Saadet Bozkurt was published in Turkey [18], however, as Özcan Bünyamin notes, the translations do not fully convey the style and manner of Shakespeare, since they are translated freely [14]. Despite this, Bülent Bozkurt's translations are extremely popular with Turkish readers, as evidenced by the almost annual reprintings of his translations (Remzi Publishing House).

Today, the tendency towards the presentation of Shakespeare's poetry to the Turkish reader is positive: the number of translators is increasing, and the translation options are varied accordingly. Most of the translators, compared to previous periods, are philologists. This can be explained by the fact that the faculties of American culture and philology, American and English philology are quite popular in Turkey in both public and private 
higher education institutions. Thus, the universities of Bilkent (Ankara), Hacettepe (since 1982), Bahçeşehir - BAU (since 2006), Ege University (Izmir) (since 1992 one of the eleven parts of the Faculty of Literature), Ankara University (Department of American Literature since 1957), Dokuz Eylül University (Izmir) (since 1992 - teaching English), Kadir Khas University (since 1997), Istanbul University (since 1982), Khalich University (1999) creates favourable conditions for young people to master English, intensive study of which takes place during the first two years of study, mastering translation techniques and acquiring knowledge of English literature.

To confirm, in Turkey nowadays appear new translations of Shakespeare, new names during 2010-2020: Hasan Ilhan (Sonnets, 2010), Ezgi Ovat (2014 Sonnets) [18]. Yeşim Misırc1, translator, graduate of the Faculty of Philology of Istanbul University (Sonnets, 2014) [19]. İn 2020, a collective work of Turkish translators of "Shakespeare's Sonnets" under the editorship of Ajda Baştan, a scholar, translator and expert in English literature, was on sale [17]. Among contemporary scholars of Shakespeare's work is the poet Edibe Toğaç (1988), who in 2012 published in the literary blog her own translations of 72 Shakespeare sonnets [21].

\section{Turkish-language dramatic translations}

\section{as a tool for cultural development of Shakespeare's world}

For the first time Shakespeare's work was presented in Turkish by the translation of the dramatic work Othello (1876) by Hasan Bedreddin Manastırl1 and Mehmet Rifat (translated from the French language), almost in sync with the appearance of the Ukrainian translation of the mentioned work by P. Kulish (1880). However, as noted by a leading researcher of Shakespeare's creativity in Turkey, Inji Enginyun, it is likely that the above translation was not made on the basis of the original, but on a rework of one of the writers of the time. The first translations of Shakespeare from the English original were made by Hasan Sirrı (The Merchant of Venice in 1884, The comedy of Errors 1887). The young translator, while adhering to the original, added the translator's notes to explain to the Turkish reader certain cultural features of the text $[8, \mathrm{p} .43]$. The translator himself remarked that, despite having a good command of the English language due to the specifics of Shakespeare's style, he sometimes needed to refer to French translations of the work to 
clarify certain points. Some translation tricks that Hasan Sirr1 resorted to at the time were interesting and justified. In most Shakespearean replicas with the word Jew he replaced the name of the hero - Shylock, probably in order to bypass possible conflicting moments [8, p. 45]. After all, Hasan Sirrı himself occupied the position of a civil servant at the time of the translation and, given the national diversity of the Ottoman state at that time, his decision to «avoid sharp corners» was correct. Reading the translation of Hasan Sirr1, it is also interesting to observe its accuracy in relation to the Turkish cultural heritage. For example, in such lines from the «Merchant of Venice» as:

By this scimitar

That slew the Sophy, and a Persian prince

That won three fields of Sultan Solyman!...

And pluck commiseration of his state

From brassy bosoms and rough hearts of flint,

From stubborn Turks, and Tartars never train'd

To offices of tender courtesy... [8, p. 46].

Hasan Sirrı completely omits Turkish realities without replacing them in other words. Modern translators periodically resort to similar techniques. For example, during his work on Pavel Zagrebelny's Turkish translation of Roxolana, Omer Dermendzhi, a scholar and expert in Ukrainian literature, personally took permission from the author to change certain parts of the text, especially those that mention Sultan Suleiman in a negative sense. As we can see, for more than a hundred years the national spirit of the Turkish nation has not diminished, the Turkish people continue to preserve historical memory without allowing it to interfere with even literary works. At the end of the nineteenth century, there were several more translations of Shakespeare's plays by Mehmet Nadir (in 1881 he translated (presumably from the French) part of the play Othello; in 1888 - part of the play Romeo and Juliet). A small pause in the translations of Shakespeare's dramas (until 1923) was conditioned by historical events in the Ottoman state (a coup d'état that brought about a reduction in the oppression of the intelligentsia, censorship, and the formation of national consciousness). At the same time, the revitalization of the theatre unions, the emergence of the Daryulbedai Educational Institution (Istanbul Local Theatre), which taught theatre art and staged plays for a wide range of audiences, facilitated the development of European literary traditions on a Turkish cultural basis. 
Referring again to I. Enginyun's research, we learn about the great interest in Shakespeare's work (after 1923) with the work of translators, writers, and poets at that time (345). Only in the thirty years (from 1927 to 1957) the Turkish version of most of Shakespeare's works have been published, translated by more than fifteen translators (Kamuran Şerif, Mehmet Şükrü, Mustafa Işıksal, Nurettin Sevin, Orhan Burian, Avni Givda, Saffet Korkut, Haldun Derin, Hamit Dereli, Yusuf Mardin).

Of great interest is the fact of active translation activities by Turkish women in the first half of the twentieth century (Seniha Bedri Göknil «King Lear» $(1937,1941,1967)$ - translation from German; Seniha Sami Moral1 - expert in English, French, «Coriolanus», «Antony and Cleopatra», «Richard III»; Belk1s Boyar «Henry VIII» (1947), expert in English literature, literary critic, scholar Berna Moran «Richard III» (1947), which confirms their high level knowledge and knowledge of foreign languages at that time. One of the most prominent writers of the Turkish Republic was and remains Halide Edip Adıvar, who was one of the first in the time of the republic to translate Shakespeare's works into Turkish. As the Dean of the Department of English Philology, she and her colleagues Vahit Turhan and Mina Urgan formed a translation group (directly from English) [8, p. 346]. The result is a translation of four Shakespeare plays from 1941 to 1949 («Hamlet», «As you like it», «Coriolanus», «Antony and Cleopatra»). The continued interest of the Turks in Shakespeare's works is confirmed by the following translations of his plays: 1959 - Adli Moran «Romeo and Juliet», İrfan Şahinbaş «King Lear, 1960 - Orhan Burian «Macbeth», 1965 - Züleyha Yılmaz «King Lear».

At the end of the 1960s, the famous Turkish playwright Turan Oflazoğlu became actively involved in the translation of dramatic works. He is one of the few contemporary playwrights in Turkey whose work is dominated by historical drama, where the sultans of the Ottoman Empire are the protagonists. The playwright declares his understanding of the genre specificity of historical drama: «You can create interesting plays without drawing on historical events. But, in my opinion, to create a play based on modern events that are still developing and it is not clear what the result will be, it is more like the desire to eat quail that is still flying in the sky. Historical events are one common reality for the whole of society. Yes, this reality is authoritarian, because it is unchanged" [12, p. 13]. Historicism, 
in his opinion, is morally supportive of modern society: «If the play's hero was able to withstand all the troubles that lay on his shoulders - I will also be able to, if he found a way out of desperation - I will also, he was also a man like me" [12, p. 12]. Together with Vahit Turhan, Turan Oflazoğlu translated «Othello» (1965), later Turan Oflazoğlu translated «Romeo and Juliet» (1968), and «The Winter's Tale» (1979).

In the 1970s, Mina Urgan, a well-known Turkish scholar of Shakespeare, and Sabahattin Eyübo Trolu translated «Troilus and Cressida». Sabahattin Eyüboğlu also translated and published independently from 1962 to 1967 «Macbeth», «Timon of Athens», «Hamlet», «Julius Caesar», «Antony and Cleopatra». Another well-known scholar of creativity in Shakespeare, scholar, teacher of the University of Hadgettepe, Bülent Bozkurt translated much of Shakespeare's works (sonnets 1979, 1994, plays) into Turkish [8, p. 350].

In the $80 \mathrm{~s}$ of the twentieth century one of the active translators of Shakespeare was a scholar, literary researcher Özdemir Nutku, who with his translations filled the gaps in the presentation of Shakespeare's work to the Turks: «The two noble kinsmen» became the last play that has not been translated before but now it has been introduced by Nutku [13, p. 440].

In the 80-90's of the twentieth century Turkish literature and dramaturgy in particular have experienced a «thematic» crisis caused by political and economic problems. Censorship, repression, bans have spread not only to the political sphere but also to the cultural sphere. Complex political conditions have displaced dramatic works that have raised important social issues, and the country's government has released actors and theatre directors. On the stages of the theatres, plays by foreign authors, such as V. Shakespeare (King Lear, Hamlet), K. Goldoni (Servant of the Two Gentlemen), M. Gogol (Examiner), E. Ionesco («The King Dies») became more active. Accordingly, new translations of foreign works began to appear. From 1992 to 2000 more than ten translations of Shakespeare's plays were published (Professor, Doctor of Philology, Connoisseur of English and Literature Engin Uzmen, Ali H. Neyzi, Engin Uzmen, Belma Yazıcığlu, Tolga Sağlam, Avni Givda) [13, p. 440].

As noted earlier, the interest of the Turkish youth in English and literature, and the presence in almost every higher education institution of Turkey of the speciality «English language and literature» contributed to the emergence of new translations of Shakespeare by specialist philologists. 
From 2002 to 2008, new translations were published in Turkey: «Macbeth» (Cangül Arda), Otello (Orhan Akıc1), A Midsummer Night's Dream (Can Doğan), Hamlet (Ümmühan Yapar), King Lear (Fatma Çolak), Henry VI. (Hamit Çalışkan), Coriolanus (Semih Kavak). The most productive in the 21 st century from the point of view of Shakespeare's dramatic translations is 2009-2010: eighteen plays, presented in translation by 15 translators. These figures cannot but rejoice [13, p. 440]. This is an indication that Turkish youth is actively developing and expanding its cultural horizons, and that despite the large number of translations that were made before the 21 st century, the process of grinding, the desire to improve translation options continues to the present, which is natural when it comes to translating works of art.

2011-2013 are not inferior to the number of translations of Shakespeare dramas - 29 plays performed by eight translators (Sibel Hüseyinca, Özgür Berkkaya, Safiye Gül Avcı, Sabri Gürses, Şefika Dönmez, Yeşim Mısırcı, Can Doğan, İhsan Toprak).

Interestingly, with the emergence of such numerous new names and variants of translation, the translations of Hamdi Çalışkan and Özdemir Nutku continue to be reissued during 2010-2015. The work of Tuna D. And Kuleli M. presents a analysis of «The comedy of errors» in translations by Bülent Bozkurt (1993) and Özdemir Nutku (2010). According to the authors, Özdemir Nutku considered the Turkish version of the translation of the play title not very correct, in his opinion, the token did not fully reflect the essence of the play, arguing that in Shakespeare's time errors had a meaningful fallacy, which should be transmitted in Turkish like yanılgl. However, because of the large number of translations available in the Turkish language of this play by Shakespeare with the name Yanlışlıklar Komedyast, he did not dare to make any significant changes to his translation [22, p. 199]. The overall analysis of both translations revealed no significant inconsistencies, the translators coped with the task and the special attention was paid to the peculiarities and subtleties of the translators intertextual, cultural aspects (with footnotes, translators' explanations). Some inaccuracies are highlighted, such as replacing neutral tokens with emotionally coloured ones (SYR. Dromio; As from a bear a man would run for life, So fly I from her that would be my wife - Insan can havliyle nasıl kaçarsa ayıdan, Öyle kaçarım ben de peşimdeki o karıdan: The word wife is translated by a rough spoken version), however, individual inaccuracies do 
not prevent both translations from being evaluated as positive. The artistic value of these translations is manifested not only in the fact that in the system of cultural relations they almost completely replace the original, but also in the fact that the limits of its perception are much wider than the translator can, when working on his text. The translators successfully coped with the task, which was to convey the ideological and emotional orientation of the original by specifying its artistic originality, which makes the work accessible and open, capable of influencing.

The provisions of the concept of O. Potebna about the secrets of the perception of a work are: receptive reading of artistic texts is «the ultimate goal of any literary work that is related to its intellectual realization in each particular consciousness» [3, p. 3]. «The descendants often value the work not for the qualities for which it was loved by contemporaries» [3, p. 19]. A literary work changes its meaning throughout its existence in a historical context, somewhat losing from the realities of its time due to the fact that these realities cease to be clear to descendants [3, p. 18]. Perhaps this can be explained by the fact that since 2015 and until today, Turkish youth continues to actively participate in translation studios, earlier translations of Shakespeare's plays are also in great demand (2015 p. Aksu Büyükalt1 The Tempest, Macbet: 2016 p. A Midsummer Night's Dream, 2015 Nesrin Kazankaya Measure for Measure).

\section{Conclusions}

The presented material demonstrates the process of entry of Shakespeare's works into Turkish literature through translation studios of the Turkish intelligentsia, stages and forms of translation process in the territory of the Ottoman state and the Turkish Republic, peculiarities of the functioning of Turkish translations of Shakespeare's poetry and dramaturgy. Analysing the existing material from translation studios, we conclude that no artistic translation, especially poetic one, can be definitive, since there are always unrealized reserves of the original hidden in the multifacetedness of its associative relations. And each translation is only a certain link, the voicing of voices in the process of functioning of the artistic image. This can be explained by the considerable number of translations in Turkish of both the poetic and dramatic works of Shakespeare from the second half of the 19th century to the present. 
The two-stage formation of Turkish-language variants of Shakespeare's poetry imprinted on the correct reading of Shakespeare; the French-language translations gave a Turkish reader some idea of the essence of Shakespeare's words, but did not reflect his works in composition. But the existence of the first stage in the translation works confirms the great desire of the Turks to reach the European literary space, the desire to learn a new, original one. The Turkish state's course on Europeanization, the popularization of foreign language learning, in particular French and English, the opening of the theatres contributed most to the translation activities in Turkey. The emergence of new translation specialists, connoisseurs of English culture, literature and especially language contributed to the discovery of the true Shakespeare by the Turks.

The best of the literary works that are experiencing their time - remain the spiritual heritage of a socially different audience, they have something to say to the next generation of readers, whose social and aesthetic preferences and landmarks are, of course, already different. The extinction and even increasing interest of the Turks in Shakespeare's creativity from the beginning of his acquaintance with her and to this day proves once again the masterpiece of Shakespeare's word.

\section{Refefences:}

1. Anykst A. A. (1963). Tvorchestvo Shekspyra [Shakespeare's literary works]. Moskva: Khudozhestvennaja lyteratura. (in Russian)

2. Ghajnicharu O.I. (1990). Poezija i mystectvo perekladu [Poetry and the art of translation]. Kyiv: Dnipro. (in Ukrainian)

3. Potebnja A. A. (1976). Estetyka i poetyka [Aesthetics and poetics]. Moskva: Yskusstvo. (in Russian)

4. Prushkovsjka I.V. (2008). «Krasa i Ljubov» Shejkha Ghaliba (do problemy indijsjkogho stylju u turecjkij literaturi): [Monoghrafija] [«Beauty and Love» by Sheikh Galib (on the problem of Indian style in Turkish literature): [Monograph]. Kyiv: Chetverta khvylja. (in Ukrainian)

5. Khalymonenko Gh.I. (2002). Istorija turecjkoji literatury (16-18 st.) [History of Turkish literature (16-18 centuries]. Kyiv: Kyivsjkyj u-t. (in Ukrainian)

6. Chyttyk U.K. (1995). V poyskakh skrytogho smysla. Sufyjskyj putj ljubvy. Dukhovnoe uchenye Rumy: Per. s angh [In search of hidden meaning. Sufi way of love. Spiritual teaching of Rumi: Per. from English]. Moskva: Ladomyr. (in Russian)

7. And M. Türkiye'de Moliere [Moliere in Turkey] // Tiyatro araştırma dergisi. Say1 5, pp. 51-64. Retrieved from://dergipark.ulakbim.gov.tr/tad/article/ view/500006995 (accessed 01 April 2021). 
8. Enginün İ. (2008). Türkçede Shakespeare [Shakespeare in Turkish]. İstanbul: Dergah yayınları.

9. Hatemi H.H. (1995). Şeyh Galib devri bilim ve kültür çevresi [Science and culture environment of Sheikh Galib era] // Şeyh Galib kitabı. İstanbul: Kültür İşleri Daire Bakanlığı, pp. 45-50.

10. İpekten H. (2005). Şeyh Galib. Hayatı, sanatı, eserleri [The life and literary works of Sheikh Galib]. Ankara: Akçağ.

11. Kahraman H.B. (2014). Değil mi kötüler kadı olmuş Yemen'e [Did not the bad people turn to Yemen?]. Sabah gazetesi. 20 Ocak 2014. Retrieved from: https://www.sabah.com.tr/yazarlar/kahraman/2014/01/20/degil-mi-ki-kotuler-kadiolmus-yemene (accessed 01 April 2021).

12. Kırc1 M. A. (2003). Turan Oflazoğlu'nun tiyatrolarında oyun kişisi olarak Osmanl padişahlar [Ottoman sultans as actors in Turan Oflazoglu's theaters]. Samsun: Deniz kültür yayınları.

13.Öncü M.T. (2017). Türkçe çeviriler bibliyografyası. Dünya edebiyatından çeviriler [Turkish translations bibliography. Translations from world literature]. İstanbul: Hiperlink eğitim kitabevi.

14. Özcan B. (2018). Şiir alanında zirve noktası: William Shakespeare soneleri [High point in the field of poetry: William Shakespeare sonnets] / Bünyamin Özcan // Sanatkaravanı dergisi. 04 Aralık Retrieved from: https://sanatkaravani.com/ william-shakespeare-soneleri/ (accessed 01 April 2021).

15. Shakespeare (2015). Soneler [Sonets]. Çev. Bülent-Saadet Bozkurt. İstanbul: Remzi kitabevi.

16. Shakespeare (2019). Soneler [Sonets]. Çev. Talat Sait Halman, İstanbul: Cem yayınevi.

17. Shakespeare'in Soneleri (2020) [Sonets]. Editör Ajda Baştan. Kolektif. Ankara: Gülnar yayınları.

18. Soneler ve Şiirler (2014) [Sonets and poems]. William Shakespeare. Çeviri Ezgi Ovat. Ankara: İtalik yayınevi.

19. Soneler. William Shakespeare [Sonets]. Editör B.C. Coşkun (2014). Çevirmen Yeşim Mısırcı. İstanbul: Parola yayınları.

20. Tanpınar A.H. (2011). 19. asır Türk edebiyatı tarihi [The history of Turkish literature in $19^{\text {th }}$ century]. İstanbul: Dergah yayınlar1.

21.Toğaç E. (2014). Shakespeare. Soneler [Sonets]. Retrieved from: http://sayfamdakalancumleler.blogspot.com/2012/04/william-shakespeare-tumsoneleri.html (accessed 01 April 2021).

22. Tuna D., Kuleli M. (2017). Çeviri gösterebilimi çerçevesinde yazınsal çeviri için bir metin çözümleme ve karşılaştırma modeli [A text analysis and comparison model for literary translation within the framework of translation semiotics]. Konya: Eğitim yayınevi. 